\title{
Effects of Telfairia occidentalis (Hook F.) Methanol Leaf Extract on the Haematological Indices and Histomorphology of the Endometrium and Liver of Female Albino Rats
}

\author{
Chidozie N. OKOYE ${ }^{1 *}$, David OGWU², John I. IHEDIOHA³, Izuchukwu S. \\ OCHIOGU $^{1}$, Anietie F. UDOUMOH ${ }^{4}$, Edmund C. MBEGBU 5 \\ ${ }^{1}$ University of Nigeria, Faculty of Veterinary Medicine, Department of Veterinary Obstetrics and Reproductive Diseases, Nsukka, Enugu State, \\ Nigeria;dr.dozie@yahoo.com; chidozie.okoye@unn.edu.ng(*orrespondingauthor);izuchukwu.ochiogu@unn.edu.ng \\ ${ }_{2}^{2}$ Ahmadu Bello University, Faculty of Veterinary Medicine, Department of Veterinary Surgery and Medicine, Zaria, Kaduna State, Nigeria; dave.ogun@yahoo.com \\ ${ }^{3}$ University of Nigeria, Faculty of Veterinary Medicine, Department of Veterinary Pathology and Microbiology, Nsukka, Enugu State, \\ Nigeria;john.ihedioha@unn.edu.ng \\ ${ }^{4}$ University of Nigeria, Faculty of Veterinary Medicine,Department of Veterinary Anatomy, Nsukka, Enugu State, Nigeria; anietie.udoumoh@unn.edu.ng \\ ${ }^{5}$ University of Nigeria, Faculty of Veterinary Medicine, Department of Physiology and Pharmacolog, Nsukka, Enugu State, Nigeria; edmund.mbegbu@unn.edu.ng
}

\begin{abstract}
The objective of this study was to evaluate the effects of administration of Telfairia occidentalis (Hook f.) methanol leaf extract on some hematological indices and histomorphology of the uterus and liver of female albino rats. Acute toxicity study of the extract was performed with female rats, following standard procedure. They were randomly assigned into 3 groups. The first group (A) served as the untreated control and received distilled water, while the second group (B) and third (C) received $200 \mathrm{and} 800 \mathrm{mg} / \mathrm{kg} \mathrm{mg} / \mathrm{kg}$ body weight of the methanol leaf extract of $T$. occidentalis respectively. Administration of the extract was done daily via the oral route for 21 days. Blood was collected for hematological evaluation at weekly intervals. Hematological parameters assessed were the packed cell volume (PCV), red blood cell (RBC) count, hemoglobin concentration (HB) and total white blood cell (TWBC) count. At the end of the study period uterine and liver tissues were excised and prepared for histological examination. Results showed that there was a significant decrease $(P<$ $0.05)$ in the mean PCV, RBC and $\mathrm{HB}$ values of the treatment groups, but only at the end of the second week of administration of the extract. There was no significant difference $(P>0.05)$ in the mean total WBC throughout the duration of the study. Histological examination of uterine and liver tissues of the different groups did not show any lesions. It was concluded that the T. occidentalis leaf methanolic extract does not adversely affect the reproductive functions of the uterus.
\end{abstract}

Keywords: endometrium, erythrocytes, haemoglobin, hepatocytes, leucocytes, uterus

\section{Introduction}

The search for alternative medicine has led to the advent of ethnomedicine which is seen as a cultural interpretation of health, diseases and illness and also addresses the healthcareseeking process and healing practices (Williams, 2006). Ethnomedicine is becoming increasingly popular among many of the world's countries, including Nigeria. This is underpinned by the fact that orthodox medicine is nearing its zenith in conventional treatment of ailments, emergence of new and drug-resistance pathogens, green revolution, as well as the fact that alternative medicine has proven to be efficacious, cost effective and readily available (Oliver-Bever, 1986). Phytomedicine, which is an integral part of ethnomedicine, is becoming the mainstay of treatment of infertility (Gaware et al., 2009; Ekere et al., 2013) in developing countries. It has played a great role in the discovery and development of many new substances of therapeutic potential (Ballick and Cox, 1997). However, there is insufficient documentation of these phytomedical practices, and they are often considered to be unreliable and that may lead to long term adverse effects (Goldstein et al., 1974; Herndon et al., 2009; Omoja et al., 2014).

Telfairia occidentalis (Hook f.) has been used extensively in the Nigerian phytomedical practice and is also widely consumed as a leafy vegetable. The plant is native to West Africa and is found cultivated as far as the Central African region. It belongs to the family Cucurbitaceace (Odiaka et al., 2004; Janick and Paull, 2008) and is popularly known as 'ugu' in the Nigerian vernacular. The plant leaf extract is used in the folkloric treatment of blood-loss anaemia due to menstrual bleeding and postpartum haemorrhage (Olaniyan and Adeleke, 2005). 
Phytochemical analysis of the plant leaf revealed the presence of alkaloids, flavonoids, glycosides, oxalates, phenols, resins, saponins, tannins, cyanide, phytins, phytate, nitrate, nitrite etc. (Oboh et al., 2006; Fasuyi and Nonyerem, 2007; Okwu and Ukanwa, 2007; Mensah et al., 2008). High content of minerals has been reported by Idris (2011) in the plant leaves. It also has a high content of iron, copper and zinc, which compares favourably with the recommended dietary allowance (NRC, 1989), thus making it a good source of mineral supplement necessary for the body's enzyme system, haematopoiesis, wound healing, growth and general well-being. This may substantiate its phytomedical use as a haematinic. Some of these phytochemicals are known to be toxic (cyanide, tannins, phytates, oxalates nitrates etc.) and have anti-nutritive properties (Fasuyi and Nonyerem, 2007; Agbede, 2008; Olaniyi and Odedere, 2009; Akang, 2011). Furthermore, iron is an obligate trace mineral that is highly toxic to tissues and cells if present in high concentration, thus its absorption and removal must be carefully controlled to avoid pathologies associated with either its deficiency or excess (Sharp and Srai, 2007).

Administration of $T$. occidentalis leaf extract had been shown to lead to some toxic effects on the male reproductive system and semen parameters (Oyeyemi et al., 2008; Saalu et al., 2010), but there are no reports on the effects of the plant leaf extract on the uterine histology of female albino rats. Salman et al. (2008) reported that the method of preparation of the extract may affect its physiologic effects; however, there is no information on the effects of the plant leaf methanolic extract on the haematological indices of female albino rats. Furthermore, regarding the liver, as the primary organ of biotransformation, it is possible that some of these noxious substances in the plant leaf extract may produce lesions in this organ. Some of these lesions may not be grossly appreciable, and can only be evaluated on histological examination. Also, the liver is one of the organs of haematopoiesis. Together with the production of erythropoietin, it also produces hepcidin, which may play a role in the regulation of haemoglobin production, thus affecting erythropoiesis. Hepcidin also controls iron absorption by the enterocytes in the small intestine and iron release from the reticuloendothelial tissues in order to become available for erythropoiesis (Nicola et al., 2002; Föller et al., 2008). Thus, pathologies of the liver may affect these functions leading to deranged haematopoiesis, which may result in altered haematological indices.

This present study was designed to evaluate the effects of the methanol leaf extract of $T$. occidentalis on haematological indices (packed cell volume (PCV), red blood cell (RBC) count, haemoglobin concentration (HB) and total white blood cell (WBC) count) and the histo-morphology of the uterus and liver of female Sprague-Dawley albino rats.

\section{Materials and Methods}

\section{Plant material}

Telfairia occidentalis vines were procured in Nsukka, Enugu State, Nigeria and then authenticated by a plant taxonomist. The leaves were hand-picked off the vine and then air-dried under shade at room temperature. The dried leaves were pulverized and then weighted. The pulverised leaves were macerated in $80 \%$ methanol for 48 hours (with intermittent agitation) and afterwards filtered using Whatman No.1 filter paper. The filtrate was concentrated to obtain a crude extract (Omale and Okafor, 2009). The crude extract was maintained at refrigeration temperature $\left(4^{\circ} \mathrm{C}\right)$ throughout the duration of the study.

\section{Animals}

Thirty-three twelve weeks old nulliparous Sprague-Dawley strain of albino rats obtained from the Animal House Laboratory of the Department of Pathology and Microbiology, Faculty of Veterinary Medicine, University of Nigeria, Nsukka were used for the study. The rats were allowed two weeks for acclimatization. The rats were kept in groups, in stainless steel cages at the experimental Animal House Unit of the Department of Veterinary Obstetrics and Reproductive Diseases of the Faculty of Veterinary Medicine, University of Nigeria, Nsukka, under standard conditions (ambient temperature: $24-28{ }^{\circ} \mathrm{C}$; day light: approximately 12 hours natural light per day; relative humidity: 50 - 60\%). Commercial pelleted feed (Vital, GCOML, Nigeria) containing 14.5\% crude protein and 2,500 Kcal/kg metabolizable energy, as well as potable water were provided ad libitum.

\section{Acute toxicity study}

Eighteen of the thirty-three rats were used for acute toxicity determination of the plant extract according to the method of Lorke (1983).

\section{Experimental design}

The fifteen nulliparous rats used for the study were randomly assigned into 3 groups of five rats each - designated A, B and C. Group A served as untreated control and received only distilled water, while groups $\mathrm{B}$ and $\mathrm{C}$ received 200 and $800 \mathrm{mg} / \mathrm{kg}$ body weight of the methanol leaf extract of $T$. occidentalis respectively for the 21 days. The extract was first emulsified in 5\% volume of Tween 20 (to enhance dissolution in distilled water).

Oral administration of the plant leaf extract was done daily ( 24 hourly) with the aid of orogastric cannula, and cageside examination was done to detect any overt signs of toxicity, morbidity or mortality.

\section{Bloodsample collection}

Blood samples for haematological study were collected weekly. The samples were collected via the ophthalmic venous plexus located in the orbital sinus through the median canthi using a micro-capillary pipette (Ihedioha et al., 2004). About 1 $\mathrm{ml}$ of blood was collected from each rat and placed into clean sample bottles containing $1 \mathrm{mg}$ of sodium ethylene diamine tetra acetic acid. The haematological analysis was done immediately upon blood sample collection. Standard procedures were adopted for the following haematological studies: - red blood cell (RBC) and total white blood cell (WBC) count was determined by the haemocytometer method using the improved Neubauer counter chamber (Hawksley, England); packed cell volume (PCV) was determined by the microhaematocrit method; haemoglobin (HB) concentration was determined by the cyanomethamoglobin method (Schalm et al., 1975). Total WBC count was determined by the haemaocytometer method using the improved Neubauer counting chamber (Hawksley, England) as described by Thrall and Weiser (2002). 
274

\section{Histology of the uterine and liver tissues}

At the end of the study interval, the rats were humanely sacrificed. The uteri and the liver were dissected out and trimmed of all adnexa. They were routinely prepared for histological examination and stained with haematoxylin and eosin (H\&E) and examined under the microscope (Drury and Wellington, 1976).

\section{Ethics}

The housing, handling and welfare of the rats used for the study were in accordance with the ethics and regulation guiding the use of research animals as approved by the University of Nigeria, Nsukka.

\section{Data analysis}

Data generated were subjected to one way analyses of variance, and variant means means were separated by the least significant difference (LSD) method. Probability less than 0.05 was considered significant. The results were presented as mean ( \pm standard deviation $(\mathrm{SD})$ ).

\section{Results}

The percentage yield of the extract was $14.57 \%$. The crude extract was observed to be oily, brownish-green in colour and not readily soluble in water; it also formed some crystalline precipitates on cooling. The extract was observed to foam on agitation in water.

Acute toxicity test showed that the extract was well tolerated at $5,000 \mathrm{mg} / \mathrm{kg}$ body weight following oral dosing.

\section{Haematological parameters \\ Erythrocytic indices}

Administration of the extract to the rat groups ( $\mathrm{B}$ and C) did not lead to any significant $(\mathrm{P}>0.05)$ variation in their PCV, HB and RBC count on week 1 and week 3 of administration, but during week 2 , the PCV, $\mathrm{HB}$ and $\mathrm{RBC}$ count of the rat groups treated with the extract was significantly $(\mathrm{P}<0.05)$ lower than that of the untreated control group (Figs. 1-3).

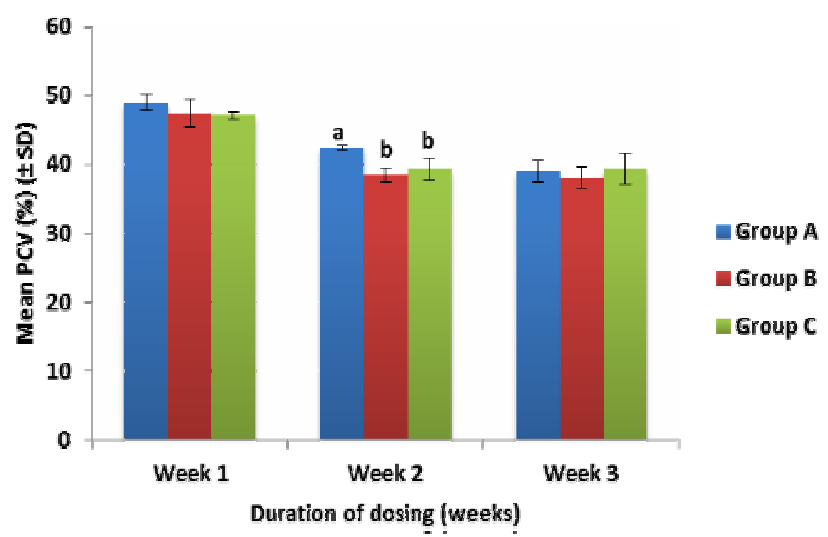

Fig. 1. The mean packed cell volume (\%) $( \pm$ SD) of rat groups given varied doses of methanolic leaf extract of $T$. occidentalis. Group A (untreated control), group B $(200 \mathrm{mg} / \mathrm{kg}$ body weight daily) and group C ( $800 \mathrm{mg} / \mathrm{kg}$ body weight daily)

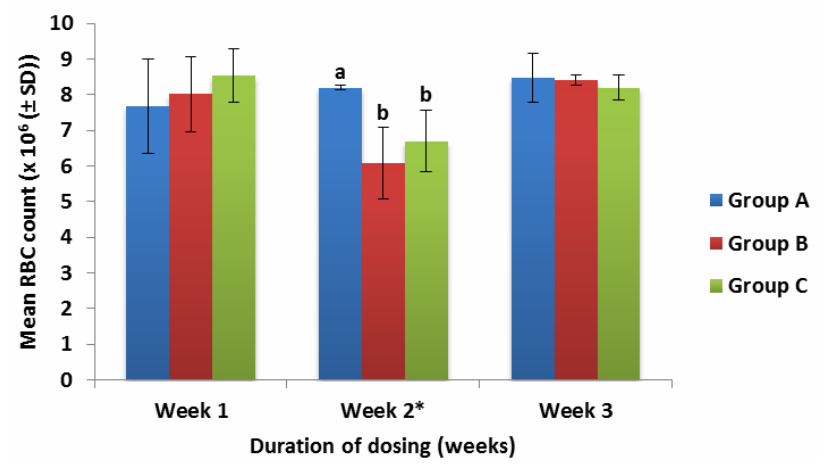

Fig. 2. The mean red blood cell count $\left(x 10^{6}\right)( \pm S D)$ of rat groups given varied doses of methanolic leave extract of $T$. occidentalis. Group A (untreated control), group B $(200 \mathrm{mg} / \mathrm{kg}$ body weight daily) and group C $(800 \mathrm{mg} / \mathrm{kg}$ body weight daily)

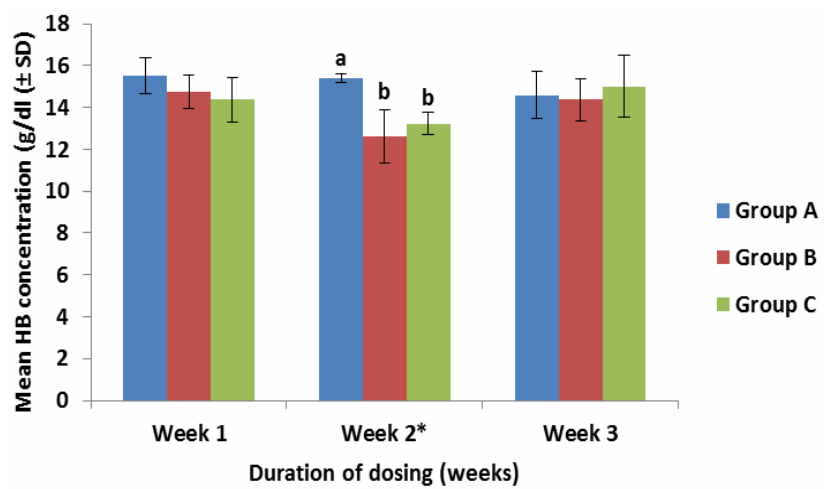

Fig. 3. The mean haemoglobin concentration $(\mathrm{g} / \mathrm{dl})( \pm \mathrm{SD})$ of rat groups given varied doses of methanolic leave extract of $T$. occidentalis. Group A (untreated control), group B $(200 \mathrm{mg} / \mathrm{kg}$ body weight daily) and group C $(800 \mathrm{mg} / \mathrm{kg}$ body weight daily)



Fig. 4. The mean total white blood cell count $\left(\mathrm{x} 10^{3} \mu \mathrm{l}\right)( \pm \mathrm{SD})$ of rat groups given varied doses of methanolic leave extract of T. occidentalis. Group A (untreated control), group B (200 $\mathrm{mg} / \mathrm{kg}$ body weight daily) and group C $(800 \mathrm{mg} / \mathrm{kg}$ body weight daily)

\section{Leucocytic indices}

There were no significant variations $(P>0.05)$ in the total WBC counts of all the rat groups all through the 3weeks study period, though at all points of sampling the mean total WBC of the group C, rats treated with $800 \mathrm{mg} / \mathrm{kg}$ body 
weight, was slightly lower than that of the other groups (Fig. 4). Examination of the processed and stained uterine and liver tissues did not show any obvious histopathologic lesions (Figs. 5 and 6).

\section{Discussion}

The erythrocytic indices obtained from the study showed that the plant extract did have effect in the haematology of female albino rats. The presence of significant decrease in the $\mathrm{PCV}$ at the end of week 2 of dosing in the study differed from the reports of Oyeyemi et al. (2008) and Salman et al. (2008), who reported significant increases in the PCV values of male albino rats that received aqueous extract of the plant for 14

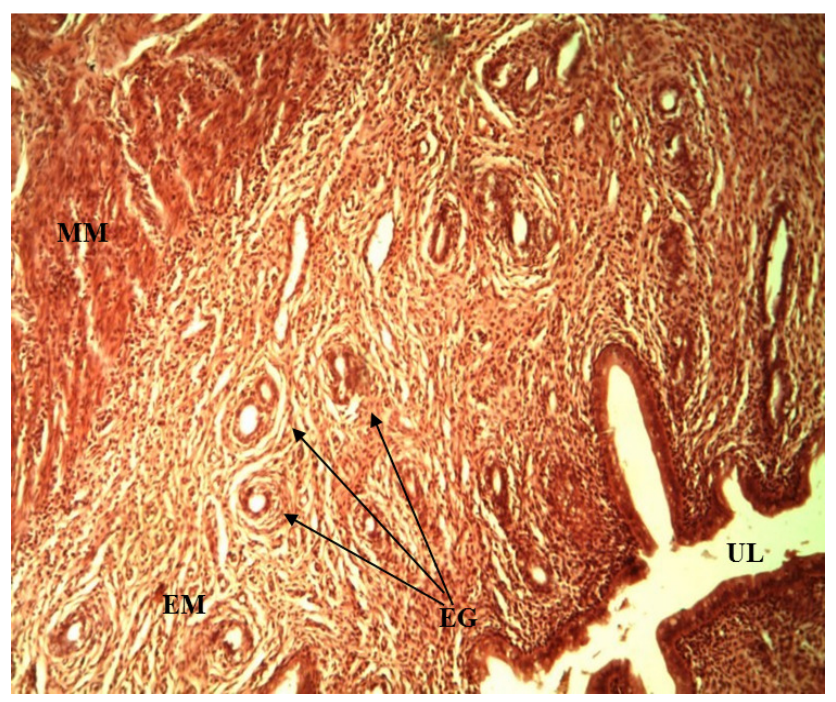

Fig. 5. Photomicrograph of a section of the uterus of group C $(800 \mathrm{mg} / \mathrm{kg})$ rats (stained with $\mathrm{H} \& \mathrm{E} ; \times 10)$. The myometrium (MM) and endometrial (EM) layers, with the endometrial layer bearing endometrial glands (EG) part of the uterine lumen (UL) are evidenced

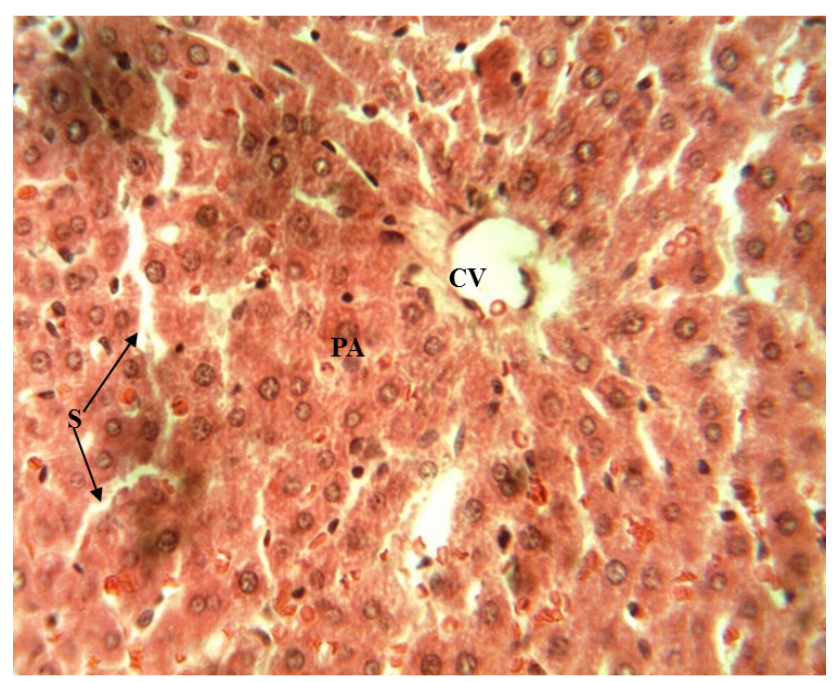

Fig. 6. Photomicrograph of a section of the liver of group $C$ $(800 \mathrm{mg} / \mathrm{kg})$ rats (stained with $\mathrm{H} \& \mathrm{E} ; \times 10)$. Seen are plates of hepatocytes separated by sinusoid in the paracentral area surrounding a central vein days. However, there were significant reduction in the RBC count and $\mathrm{HB}$ concentration only at the end of the second week of dosing in the two treatment groups. By the end of the third week of dosing there were no significant differences in the values of the RBC count and $\mathrm{HB}$ concentration of the treatment groups when compared to that of the control. Nevertheless, the $\mathrm{HB}$ and $\mathrm{RBC}$ values from this study were higher than that reported by Ihedioha et al. (2004) for female Sprague-Dawley outbreed albino rats in the same geographic location and of the same age range, except for the RBC count of the group $\mathrm{C}$ in the second week of dosing.

Dietary iron is seen in two forms - the haem (from animal products) and non-heam (from plants). The nonhaem form predominates (90-95\%) but is less bioavailable and only (1-10\%) is absorbed. Anti-nutrients such as phytates and polyphenols present in the studied plant are inhibitors of non-haem absorption (Sharp and Srai, 2007). The proposed mucosal block hypothesis - whereby absorption of a high dose of iron initially may affect subsequent absorption hours later (Sharp and Srai, 2007), thus may account for the significant reduction in the $\mathrm{RBC}$ and $\mathrm{HB}$ values seen only in the second week.

The no significant difference in the total white blood cell count between treatment groups when compared to that of the control in the current study is corroborated by the report of Iweala and Obidoa (2009).

Sections of the endometrium did not present any obvious abnormal features on histopathological examination in the different groups of rats. There were no lesions in the myometrium or endometrium. There were endometrial glands in these sections in all the groups, showing that the extract had no pathological effect on the endometrium. There were no pathological features in the lamina propria of the endometrium or in the surface epithelium of the endometrium, likewise also in the myometrium of the uterus. This indicates that the extract had no effect on the cyclical activity of the uterus, which could signify that the extract had little or no effect on the ovary that controls the cyclical activities of the uterus through the hypothalamo-pituitaryovarian-uterine axis.

This show that the extract may not be adversely affecting the female reproductive tract (uterus) and hence their functions, unlike in the males, as reported by (Oyeyemi et al., 2008; Salman et al., 2008; Saalu et al., 2010).

\section{Conclusions}

The absence of obvious liver histopathological lesions observed in the hereby study showed that the extract may not be toxic to the tissues of the organ at the doses administered. Based on the results of the study it can be concluded that the T. occidentalis leaf methanol extract does not adversely affect the reproductive functions of the uterus, but may not be a very good supplement for treatment of anaemia.

\section{References}

Agbede JO, Adegbenro M, Onibi GE, Oboh C, Aletor VA (2008). Nutritive evaluation of Telfairia occidentalis leaf protein concentrate in infant foods. African Journal of Biotechnology $7(15): 2721-2727$. 
276

Akang E, Oremosu A, Dosumu O, Ejiwunmi A (2011). Telfairia occidentalis, a prophylactic medicine for alcohol's damaging effect on the testis. Macedonian Journal of Medical Sciences 4(4):380-387.

Ballick M, Cox P (1997). Plants, people and culture: the science of ethnobotany. New York (1st Ed), Scientific American Library.

Drury RA, Wellington EA (1976). Carleton's histological technique. Oxford University Press (4th Ed) London pp 120-123.

Ekere SO, Okoye CN, Udoumoh AF (2013). Fertility enhancing effects of methanolic leaf extract of Dracaena arborea in albino rats (Rattus norvegicus). Czech Journal of Animal Science 58 (11):520-524.

Fasuyi AO, Nonyerem AD (2007). Biochemical, nutritional and haematological implications of Telfairia occidentalis leaf meal as protein supplement in broiler starter diets. African Journal of Biotechnology 6(8):1055-1063.

Föller M, Hubber SM, Lang F (2008). Erythrocyte programmed cell death. Life 60(10):661-668.

Gaware VM, Parjance SK, Merekar AN, Pattan SR, Dighe NS, Kuchekar BS, Godge RK (2009). Female infertility and its treatment by alternative medicine: a review. Journal of Chemical and Pharmaceutical Research 1:148-162.

Goldstein A, Aronow L, Kalman SM (1974). Principles of drug action: the basis of pharmacology. New York (2nd Ed), Wiley.

Herndon CN, Uiterloo M, Uremaru A, Plotkin M, Emanuels-Smith G, Jitan J (2009). Disease concepts and treatment by tribal healers of an Amazonian forest culture. Journal of Ethnobiology and Ethnomedicine 5:27.

Idris S (2011). Compositional studies of Telfaria occidentalis leaves. American Journal of Chemistry 1(2):56-59.

Ihedioha JI, Okafor C, Ihedioha TI (2004). The haematological profile of the Sprague-Dawley outbred albino rat in Nsukka, Nigeria. Animal Research International 1(2):125-132.

Iweala EJ, Obidoa O (2009). Some biochemical, haematologic and histological responses to a long term consumption of Telfairia occidentalis-supplemented diet in rats. Pakistan Journal of Nutrition 8(8):1199-1203.

Janick J, Paull RE (2008). The encyclopedia of fruits and nuts. CAB International. Oxfordshire, United Kingdom pp 310-312.

Lorke D (1983). A new approach to practical acute toxicity testing. Archives of Toxicology 54:275-287.

Oboh G, Nwanna EE, Elusiyan CA (2006). Antioxidant and antimicrobial properties of Telfairia occidentalis (fluted pumpkin) leaf extracts. Journal of Pharmacology and Toxicology 1(2):167175.

Odiaka NI, Schippers RR (2004). Vegetables. In: Grubben GJH, Denton AO (Eds). Plant resources of tropical Africa (2nd Ed) PROTA Foundation, Netherlands and Backhuys Publishers, Wageningen Netherlands pp 520-550.

Okwu DE, Ukanwa NS (2007). Nutritive value and phytochemical contents of fluted pumpkin (Telfaria occidentalis Hook f.) vegetable grown with different levels of turkey droppings. African Crop Science Conference Proceedings 8:1759-1964.
Olaniyan MF, Adeleke A (2005). A study of the effect of pumpkin (ugu - Telfaria occidentalis) milk and raw egg mixture in the treatment of anaemic pregnant women in a rural area. African Journal of Traditional Complementary and Alternative Medicines 2(3):269-273.

Olaniyi TO, Odedere MP (2009). The effect of mineral nitrogen and compost fertilizers on the growth, yield and nutritional values of fluted pumpkin (Telfaria occidentalis) in South Western Nigeria. Journal of Animal and Plant Sciences 5(1):443-449.

Oliver-Bever P (1986). Medicinal plant in tropical West Africa. Cambridge University Press, London.

Omale J, Okafor P (2009). Cytotoxicity and antioxidant screening of some selected Nigerian medicinal plants. Asian Journal of Pharmaceutical and Clinical Research 2(4):48-53.

Omoja VU, Ekere SO, Okoye CN, Mbegbu EC (2014). Leucopoetic and testosterone levels of rats administered sub-chronic methanolic leaf extract of Dracaena arborea. Comparative Clinical Pathology 24:527-532.

Oyeyemi M, Leigh O, Ajala O, Badejo A, Emikpe B (2008). The effects of the aqueous extract of 'ugu' (Telfairia occidentalis) leaves on the testis and spermatozoa characteristics in the male albino rat. Folia Veterinaria 52(2):102-105.

Mensah JK, Okoli RI, Ohaju-Obodo, Eifediyi K (2008). Phytochemical, nutritional and medical properties of some leafy vegetable consumed by Edo people of Nigeria. African Journal of Biotechnology 7(14):2304-2309.

National Research Council (NRC) (1989). Recommended dietary allowances. Washington DC (10th Ed). The National Academic Press.

Nicolas G, Bennoun M, Porteu A, Mativet S, Beaumont C, Grandchamp B, ... Vaulont S (2002). Severe iron deficiency anemia in transgenic mice expressing liver hepcidin. Proceedings of the National Academy of Science 9(7):4596-4601.

Saalu LC, Kpela T, Benebo A, Oyewopo A, Anifowpe E, Oguntola J (2010). The dose-dependent testiculo-protective and testiculotoxic potentials of Telfairia occidentalis Hook $\mathrm{f}$. leaves extract in rats. International Journal of Applied Research in Natural Products 3(3):27-28.

Salman TM, Olayiki AL, Oyeyemi WA (2008). Aqueous extract of Telfairia occidentalis leaves reduces blood sugar and increases haematological and reproductive indices in male rats. African Journal of Biotechnology 7(14):2299-2303.

Schalm OW, Jain NC, Caroll EJ (1975). Veterinary haematology. Lea and Febiger (3rd Ed), Philadelphia.

Sharp P, Srai SK (2007). Molecular mechanisms involved in intestinal iron absorption. World Journal of Gastroenterology 13(35):4716-4724.

Thrall MA, Weiser MG (2002). Hematology. In: Hendrix CM (Ed). Laboratory procedures for veterinary technicians. Mosby (4th ed) Missouri pp 29-74.

Williams L (2006). Ethnomedicine. West Indian Medical Journal 55(4):215. 